\title{
Evaluation of three rape seed commodities in the rumen of steers 1. Degradation of dry matter and crude protein and disappearance of amino acids in situ
}

\author{
K.-H. Südekum and Helga Andree' \\ Institute of Animal Nutrition, Physiology and Metabolism, \\ Christian-Albrechts-University \\ D-24098 Kiel, Germany
}

(Received 11 July 1996; accepted 6 February 1997)

\begin{abstract}
Ruminal degradation characteristics of rape seed and of untreated and formaldchyde-treated rapeseed meals containing less than $8 \mu \mathrm{mol}$ of total glucosinolates per gram of dry matter were investigated. Feeds were incubated in polyester bags in the rumen of three fistulated steers for $0,2,4$, $8,16,24$ and $48 \mathrm{~h}$. The rate and extent of degradation of dry matter and crude protein and disappearance of amino acids from polyester bags were determined. The crude protein was more degradable than the dry matter of rape seed and untrealed rapeseed meal, whereas the opposite was observed for the formaldehyde-treated rapeseed meal. The treatment of the rapeseed meal with formaldehyde greatly reduced the rate and extent of dry matter and crude protein degradation compared with the untreated meal. Effective degradabilities of dry matter and crude protein declined in the following order: rape seed $>$ untreated rapeseed meal $>$ formaldehyde-treated rapeseed meal. The effective degradabilities of crude protein at assumed ruminal passage rates of 2,5 and $8 \% / \mathrm{h}$ ranged from 77 to $62 \%$ for the rape seed, 76 to $51 \%$ for the untreated meal and 39 to $16 \%$ for the formaldehyde-treated meal. With increasing exposure time to the rumen, the amino acid profile of undegraded residues of rape seed and of untreated rapeseed meal changed. As a result, large differences among amino acids were observed for percentages of disappearance from the bags. Treatment of rapeseed meal with formaldehyde was effective in preserving the amino acid composition of the undegraded feed protein.
\end{abstract}

KEY WORDS: rape seed, rapeseed meal, formaldehyde, rumen degradation, crude protein, amino acids

'Current address: Institute of Agricultural Engineering, Christian-Albrechts-University, 24098 Kiel, Germany 


\section{INTRODUCTION}

Rape seed and rapeseed meal (RSM) have long been considered to be inferior animal feeds. The breeding and introduction into agricultural practice of rape seed varieties containing reduced and low levels of erucic acid and glucosinolates have increased the potential of rape seed and RSM as animal feedstuffs (Bell, 1993). Ruminal crude protein (CP) degradation of RSM of varieties containing moderate to high levels of glucosinolates has thoroughly been investigated. Hill (1991) estimated that the ruminal degradability of CP in RSM ranged from 59 to $77 \%$. Subuh et al. (1994) reported that low glucosinolate RSM had lower ruminal degradabilities of $\mathrm{CP}$ than high glucosinolate RSM. Ruminal CP degradability of whole rape seed may be different from that of RSM (Mir et al., 1984; Deacon et al., 1988). Reports on ruminal degradation of rape seed and RSM are inconsistent with respect to the effect on the amino acid (AA) composition of the feeds after ruminal exposure. In situ ruminal degradation altered the AA profile of RSM (Varvikko, 1986) and rape seed (Antoniewicz et al., 1992a), but had no effect on the AA profile of RSM in another study (Varvikko et al., 1983). Treatment of RSM with formaldehyde dramatically reduced ruminal degradation of CP (Rooke et al., 1983; Bailey and Hironaka, 1984) and was effective in preserving the original AA profile of RSM after ruminal incubation (Setälä and Syrjälä-Qvist, 1984). Because the quantity and quality of AA supply to high-yielding dairy cows depends on AA from microbial and ruminally undegraded $\mathrm{CP}$, changes in the AA profile of feeds during ruminal incubation will alter the contribution of individual AA to the supply of the dairy cow.

The objectives of this study were to determine the characteristics of ruminal dry matter (DM) and CP degradation of three rape seed commodities and to study the AA profiles of feeds and their undegraded residues after in situ ruminal incubation.

\section{MATERIAL AND METHODS}

\section{Rape seed commodities}

Three commercially available rape seed commodities were used, namely rape seed, RSM and formaldehyde-treated RSM (FRSM; Bioprofin ${ }^{(\mathrm{k})}$ ). The RSM and FRSM were from the same batch of feed. Gaseous formaldehyde $(1.1 \mathrm{~g} / \mathrm{kg}$ RSM), released from a mixture of formaldehyde and Sipernat ${ }^{(\bar{B})}$ (Degussa $A G$, Frankfurt/M., Germany) under controlled temperature and pressure, was used to produce the FRSM (A. Helmedach, personal communication, 1995). The chemical composition of the three feeds is presented in Table 1. 
TABLE 1

Chemical composition of the rape seed commodities, $\mathrm{g} / \mathrm{kg}$ dry matter

\begin{tabular}{lccc}
\hline & Rape seed & Rapesced mcal & $\begin{array}{c}\text { Formaldehyde-trealed } \\
\text { rapeseed meal }\end{array}$ \\
\hline Crude Protein & 224 & 360 & 353 \\
Ether extract & 360 & 58 & 59 \\
Acid ether extract & 426 & 74 & 76 \\
Crude fibre & 172 & 147 & 149 \\
Ash & 52 & 72 & 78 \\
Formaldehyde & ND $^{\text {b }}$ & ND & 0.88 \\
Total glucosinolates & & & 7.0 \\
( $\mu$ mol/g dry malter) & 7.6 & 6.5 & \\
\hline
\end{tabular}

${ }^{a}$ acid hydrolysis prior to extraction

${ }^{b}$ not determined

\section{Animals and feeding}

Three ruminally fistulated Angler Rotvieh steers were fed on a diet consisting of (DM basis) $36 \%$ maize silage, $28 \%$ grass silage, $27 \%$ commercial dairy concentrate and $9 \%$ rape seed mix (containing equal proportions of the three rape seed commodities used for ruminal incubation). The DM of the diet contained $15 \% \mathrm{CP}, 5 \%$ acid hydrolysis ether extract and $21 \%$ crude fibre. The diet was supplemented with a commercial mineral and vitamin mixture. The daily allotment of feed was offered in two equal meals at 07:00 h and 19:00 h. Prior to feeding, all dietary ingredients were completely mixed by hand. Daily DM intake was $9.0 \mathrm{~kg}$ per animal, which was close to calculated maintenance energy requirements of the steers. The steers had continuous access to water. Prior to the experiment, an adjustment period of two weeks was allowed for dietary adaptation.

\section{In situ procedure}

The rumen incubations of the three rape seed commodities were arranged according to a $3 \times 3$ Latin square design. Bags made of polyester (Polyester Monofilament, PES 40/27, Swiss Silk Bolting Co. Lid., Zurich, Switzerland) with rounded corners were used for incubation. They were $9 \times 14 \mathrm{~cm}$ in size with a pore size of $40 \mu \mathrm{m}$, square-like pores and an open surface area of $27 \%$. Five grams of an air-dried sample ground to pass a $3 \mathrm{~mm}$ screen were placed in each bag, which was anchored with a $30 \mathrm{~cm}$ length of braided fishing line. Prior to incubation, the bags were soaked in warm water $\left(38^{\circ} \mathrm{C}\right)$ for $10 \mathrm{~min}$. On day 1 of incubation, the bags were clamped to an $800 \mathrm{~g}$ cylindrical plastic weight, which 
was tied to a $80 \mathrm{~cm}$ long main line tied outside the fistula. All bags were inserted into the ventral sac of the rumen at $07: 00 \mathrm{~h}$ immediately before the morning feeding. Incubation periods were $2,4,8,16,24$ and $48 \mathrm{~h}$. Two bags were used per incubation period. This protocol was repeated two days later for a total of 24 observations per feedstuff and animal. Immediately after removal from the rumen, bags were immersed in ice-water to stop or minimize microbial activity and then washed in a washing machine with cold water for $35 \mathrm{~min}$. Zero time disappearance values $(0 \mathrm{~h})$ were obtained by washing pre-soaked, unincubated bags in quadruplicate in a similar fashion. Water-soluble material (WS) was estimated by washing a sample through a folded filter paper (No. 595/2, Schleicher and Schuell, Dassel, Germany). All washed bags and filter paper residues were dried in a forced-air oven at $60^{\circ} \mathrm{C}$ for $48 \mathrm{~h}$. Water-insoluble DM, $\mathrm{CP}$ and AA escaping in small particles (SP) from the bags during washing were estimated by subtracting water-soluble DM, CP and AA from $0 \mathrm{~h}$ values. The percentages of disappearance of DM, CP and AA were calculated from the proportion remaining after incubation in the rumen. The single values obtained for disappearance (Di) were then corrected for SP by the equation (Weisbjerg et al., 1990):

$$
\mathrm{CD}_{\mathrm{i}}=\mathrm{D}_{\mathrm{i}}-\mathrm{SP} \times\left(1-\left(\left(\mathrm{D}_{\mathrm{i}}-(\mathrm{SP}+\mathrm{WS})\right) /(1-(\mathrm{SP}+\mathrm{WS})) .\right.\right.
$$

Thus, CD of $0 \mathrm{~h}$ values equals the water-soluble fraction of DM and DM constituents. Potential microbial contamination of feed residues after ruminal exposure was not taken into account. Varvikko and Lindberg (1985) and Varvikko (1986) reported that microbial CP and AA did not greatly bias estimates of in situ disappearance of $\mathrm{CP}$ and $\mathrm{AA}$ from protein-rich fecds including rape seed. Degradation of DM and CP was calculated using the equation of McDonald (1981):

$$
C D=a+b\left(1-e^{-c(t-L)}\right) \text { for } t>L,
$$

where $\mathrm{CD}=$ disappearance rate at time $\mathrm{t}$ corrected for $\mathrm{SP}, \mathrm{a}=\mathrm{an}$ intercept representing the portion of DM $(\mathrm{CP})$ solubilized at initiation of incubation (time 0 ; soluble fraction), $\mathrm{b}=$ the fraction of $\mathrm{DM}(\mathrm{CP})$ insoluble but degradable in the rumen (slowly degradable fraction), $c=a$ rate constant of disappearance of fraction $b, t=$ time of incubation and $L=$ lag phase. The nonlinear parameters $a$, b, cand $\mathrm{L}$ were estimated by an iterative least squares procedure (SAS, 1988), and best-fit values were chosen with the DUD option under the restriction $(a+b) \leqslant 100 \%$. The effective degradability of DM and CP was calculated using the following equation (McDonald, 1981):

$$
\text { Effective degradability of DM }(C P)=a+(b c /(c+k)) \times e^{-(c+k) L} \text {, }
$$

where $\mathrm{k}$ is the estimated rate of outflow from the rumen, and $\mathrm{a}, \mathrm{b}, \mathrm{c}$ and $\mathrm{L}$ are the same parameters as described earlier. The effective degradability of DM and CP 
was estimated assuming rumen solid outflow rates of 2,5 and $8 \%$ per $h$, which is representative for low, medium, and high feeding amounts (Agricultural Research Council, 1984).

\section{Chemical analysis}

Feedstuffs were ground successively to pass through 3- and 1-mm screens. Residues from polyester bag incubations were ground in a water-cooled laboratory mill (IKA A 10; Janke and Kunkel, Staufen i. Br., Germany). Polyester bag residues incubated on the same day were pooled by feedstuff, animal, and incubation time for the analysis of DM and CP giving a total of 6 observations ( 3 animals $\times 2$ day replicates nested within period) for statistical analysis. Residues were composited by feedstuff and incubation time for AA analyses resulting in one observation per feedstuff and incubation time ( 7 observations per feedstuff including 0 -h disappearance). Dry matter and approximate constituent analyses in feedstuffs and polyester bag residues were performed according to standard procedures (Bassler, 1976). Samples for AA analyses were hydrolyzed in $6 \mathrm{M} \mathrm{HCl}$ at $132^{\circ} \mathrm{C}$ in an autoclave for $3 \mathrm{~h}$. For sulphur AA, samples were oxidized with hydrogen peroxide:formic acid $(1: 9, \mathrm{v} / \mathrm{v})$ at $4^{0} \mathrm{C}$ for $24 \mathrm{~h}$, followed by $6 \mathrm{M} \mathrm{HCl}$ at $132^{\circ} \mathrm{C}$ in an autoclave for $3 \mathrm{~h}$. Amino acids were analysed by ion-exchange chromatography in a AA analyser (Model T 339 M; Microtechna, Prague). Formaldehyde (in FRSM only) was analysed using steam distillation and colour reaction with chromotropic acid. Readings were made at 570 $\mathrm{nm}$ (method 14.15.1; Bassler, 1976). Total glucosinolates in the three rape seed commodities and in polyester bag residues after 4 and $8 \mathrm{~h}$ of ruminal incubation (composited across animals) were analysed by HPLC according to method 1864/90 of the European Communities (Anonymous, 1990).

\section{Statistical methods}

Percentage disappearance of DM and CP from the polyester bags was analysed by the mixed model procedure of SAS (1992). The model was

$$
\begin{array}{ll}
Y_{i j k m n}=M+F_{i} & +A_{j}+P_{k}+D(P)_{l k}+T_{m}+(F x T)_{i m}+(A x T)_{j m}+(P x T)_{k m}+B_{i j k l m n}, \\
\text { where } & \\
Y & =\text { observed response } \\
M & =\text { overall mean } \\
F_{i} & =\text { effect of feedstuff } i \\
A_{j} & =\text { effect of animal } j \\
\mathbf{P}_{k} & =\text { effect of period } k \\
D(P)_{l k} & =\text { effect of day replicate } 1 \text { nested within period } k
\end{array}
$$


$\mathrm{T}_{\mathrm{m}} \quad=$ effect of incubation time $\mathrm{m}$

$(\mathrm{FxT})_{\mathrm{im}}=$ effect of interaction between feed $\mathrm{i}$ and incubation time $\mathrm{m}$

$(\mathrm{AxT})_{\mathrm{jm}}=$ effect of interaction between animal 1 and incubation time $\mathrm{m}$

$(\mathrm{PxT})_{\mathrm{km}}=$ effect of interaction between period $\mathrm{k}$ and incubation time $\mathrm{m}$ and

$\mathrm{B}_{\mathrm{ijkkjmn}}=$ residual error of the bag (degrees of freedom $=25$ ), with assumed first-order autoregressive covariance structure.

Comparisons among the three feeds at each incubation time were performed using the CONTRAST statement within the mixed model procedure.

\section{RESULTS}

\section{Glucosinolates}

After 4 and $8 \mathrm{~h}$ of ruminal incubation of the three feeds, the concentrations of total glucosinolates were reduced to less than $1 \mu \mathrm{mol} / \mathrm{g}$ residue, which represents the detection limit (data not shown).

\section{Dry matter and crude protein degradation}

Dry matter and CP disappearance data for the rape seed commodities are reported in Table 2. Analyses of variance of DM and CP disappearance values revealed effects $(P<0.001)$ of feed, incubation time and the interaction of feed and incubation time. Differences between each of the three feeds in DM and CP disappearance were significant at each incubation time $(\mathbf{P}<0.01$ to $\mathbf{P}<0.001)$. Animal effects $(\mathrm{P}<0.01)$ were detected only for $\mathrm{DM}$ disappearance after 8 and $16 \mathrm{~h}$ of ruminal incubation. At each incubation time, the extent of DM and CP disappearance decreased in the order: rape seed $>$ RSM $>$ FRSM. Only the 0 -h values (DM) and the $48 \mathrm{~h}$ values (CP) were higher for RSM than for rape seed. The FRSM largely differed from rape seed and RSM, and the differences were more pronounced for CP than for DM.

Nonlinear parameter estimates and effective degradability values of DM and $\mathrm{CP}$ are presented in Table 3. A lag phase was estimated for the DM of all three feeds. However, a lag phase prior to CP degradation occurred obviously only in FRSM. The soluble (a) DM fraction was similar among the rape seed commodities, whereas it was more than two-fold higher for $\mathrm{CP}$ of rape seed than of RSM and FRSM. The magnitude of the $b$ fraction of DM decreased in the order FRSM, rape seed and RSM, but for CP, it decreased in the order FRSM, RSM and rape seed. The rate constant of disappearance of the $b$ fraction of DM and CP was highest in rape seed, intermediate in RSM and very low in FRSM. In the two meals, the rate constant of DM disappearance was slightly higher than 
TABLE 2

Fiffect of ruminal incubation time on disappearance ( $\%)$ of dry matter (DM) and crude protein (CP) from polyester bags

\begin{tabular}{|c|c|c|c|c|c|c|c|c|c|}
\hline & \multirow{2}{*}{$\frac{\text { Washing }}{\operatorname{loss}^{\mathrm{b}}}$} & \multicolumn{8}{|c|}{ Incubation time, $\mathrm{h}$} \\
\hline & & 0 & 2 & 4 & 8 & 16 & 24 & 48 & SEM \\
\hline \multicolumn{10}{|c|}{$\overline{\text { Rape seed }}$} \\
\hline DM & 24.8 & 18.5 & 29.3 & 37.3 & 60.6 & 78.6 & 81.6 & 85.1 & 0.01 \\
\hline $\mathrm{CP}$ & 38.8 & 24.3 & 38.5 & 48.2 & 69.9 & 82.8 & 86.2 & 89.0 & 0.02 \\
\hline \multicolumn{10}{|c|}{ Rapeseed meal } \\
\hline DM & 29.7 & 21.3 & 22.4 & 30.6 & 50.7 & 66.9 & 72.8 & 80.7 & 0.01 \\
\hline $\mathrm{CP}$ & 23.0 & 10.1 & 22.6 & 29.7 & 50.8 & 69.9 & 79.3 & 92.0 & 0.02 \\
\hline \multicolumn{10}{|c|}{ Formaldehyde-treated rapeseed meal } \\
\hline DM & 18.5 & 17.3 & 16.6 & 17.9 & 23.1 & 39.5 & 47.5 & 67.7 & 0.01 \\
\hline $\mathrm{CP}$ & 53.6 & 9.4 & 8.8 & 8.9 & 11.8 & 21.5 & 28.1 & 66.4 & 0.02 \\
\hline
\end{tabular}

a values for disappearance were corrected for DM or CP escaping in small particles from the bags during washing according to Weisbjerg et al. (1990). Corrected disappearance of 0 -h values equals the water-soluble fraction

c washing loss equals 0 -h disappearance without correction for escape of small particles

TABLE 3

Nonlinear estimates and effective degradability values of dry matter (DM) and crude protein (CP)

\begin{tabular}{lcccccccc}
\hline & & & \multicolumn{5}{c}{ Effective degradability $^{a^{\prime}}$} \\
& $\mathrm{a}^{\mathrm{b}}$ & $\mathrm{b}$ & $\mathrm{c}$ & lag & undegraded $^{\mathrm{c}}$ & $2 \%$ & $5 \%$ & $8 \%$ \\
\hline Rape seed & & & & & & & & \\
DM & 18.5 & 67.1 & 13.5 & 1.0 & 14.4 & 68.6 & 59.2 & 52.5 \\
CP & 24.3 & 64.4 & 15.2 & 0.5 & 11.3 & 76.7 & 68.2 & 62.0 \\
Rapeseed meal & & & & & & & \\
DM & 21.3 & 59.1 & 10.4 & 1.9 & 19.6 & 60.5 & 51.1 & 44.8 \\
CP & 10.1 & 83.2 & 7.9 & 0.1 & 6.7 & 75.8 & 60.4 & 50.8 \\
Formaldehyde-treated rapesced meal & & & & & \\
DM & 16.7 & 69.5 & 3.0 & 3.8 & 13.8 & 51.2 & 35.9 & 29.2 \\
CP & 9.8 & 90.2 & 2.2 & 11.9 & 0 & 38.5 & 21.5 & 15.8 \\
\hline
\end{tabular}

a effective degradability at three ruminal passage rates

${ }^{b} \mathrm{a}=$ the portion (percentage) of DM or CP solubilized at initiation of incubation; $b=$ the fraction (percentage) of DM or CP insoluble but degradable in the rumen; $c=$ the constant rate (percentage per $h$ ) of disappearance of fraction $b$; lag $=$ lag phase $(h)$ prior to the commencement of degradation of fraction $b$

${ }^{c}$ undegraded $=100-(a+b)(\%)$ 
that of $\mathrm{CP}$, whereas in rape seed, the rate constant of $\mathrm{CP}$ was higher. The undegraded fraction of $\mathrm{CP}$ was smaller for the two meals than for rape seed, and was higher for DM than for CP of all three feeds. Due to the low rate constant of disappearance of the $b$ fraction in FRSM, effective degradabilities of DM and CP largely differed between RSM and FRSM. The values for effective degradability of DM and CP were greatest in rape seed.

\section{Amino acids}

The AA composition of the feeds and the polyester bag residues after ruminal incubation is presented in Table 4 . The CP of rape seed contained more AA than the CP of the two meals, which were similar in their AA content owing to the fact that they were from the same batch of feed. Compared with the feeds, the washing procedure ( 0 -h values) led to an increase in the AA content of the CP of all three feeds. The decline in the AA concentrations with increasing exposure time to the rumen was faster and greater for rape seed than for RSM and FRSM. The two meals differed after 24 and $48 \mathrm{~h}$ of ruminal incubation, when concentrations of total AA and individual AA were higher for FRSM than RSM.

The comparison of the AA profile of the original and undegraded protein of polyester bag residues exposed to the rumen (Figure 1) point to marked differences between the three feeds. A value of 1 indicates that the proportion of an AA of total AA remained constant throughout ruminal exposure. Values higher than 1 indicate a slower than average degradation of an AA and values lower than 1 indicate a faster than average degradation of an AA. The AA of rape seed and RSM had values from below 0.7 to above 1.3, whereas in FRSM, only few AA had values lower than 0.9 or higher than 1.1, indicating a similar rate of disappearance from this feed for all AA. The magnitude of the changes in the AA profile within feeds clearly increased with increasing ruminal incubation time.

The effect of ruminal incubation time on disappearance of AA from polyester bags is presented in Table 5. Values of AA disappearance followed the general trend observed for $\mathrm{CP}$, i. e., up to $24 \mathrm{~h}$ of ruminal incubation, disappearance of AA from rape seed commodities declined in the order: rape seed $>$ RSM $>$ FRSM. After $48 \mathrm{~h}$ of ruminal incubation, however, values for disappearance of AA were higher for RSM than rape seed. Irrespective of duration of ruminal incubation, the AA of FRSM had the lowest disappearance values. Among the essential AA (EAA), the branched-chain AA of all three feeds had slightly but consistently lower disappearance values than the other EAA. Histidine and arginine were the EAA that disappeared to the greatest extent in the first hours of ruminal incubation from rape seed and RSM. Among the non-essential AA (NEAA) of these two feeds, glutamic acid and proline disappeared more rapidly than the others. 


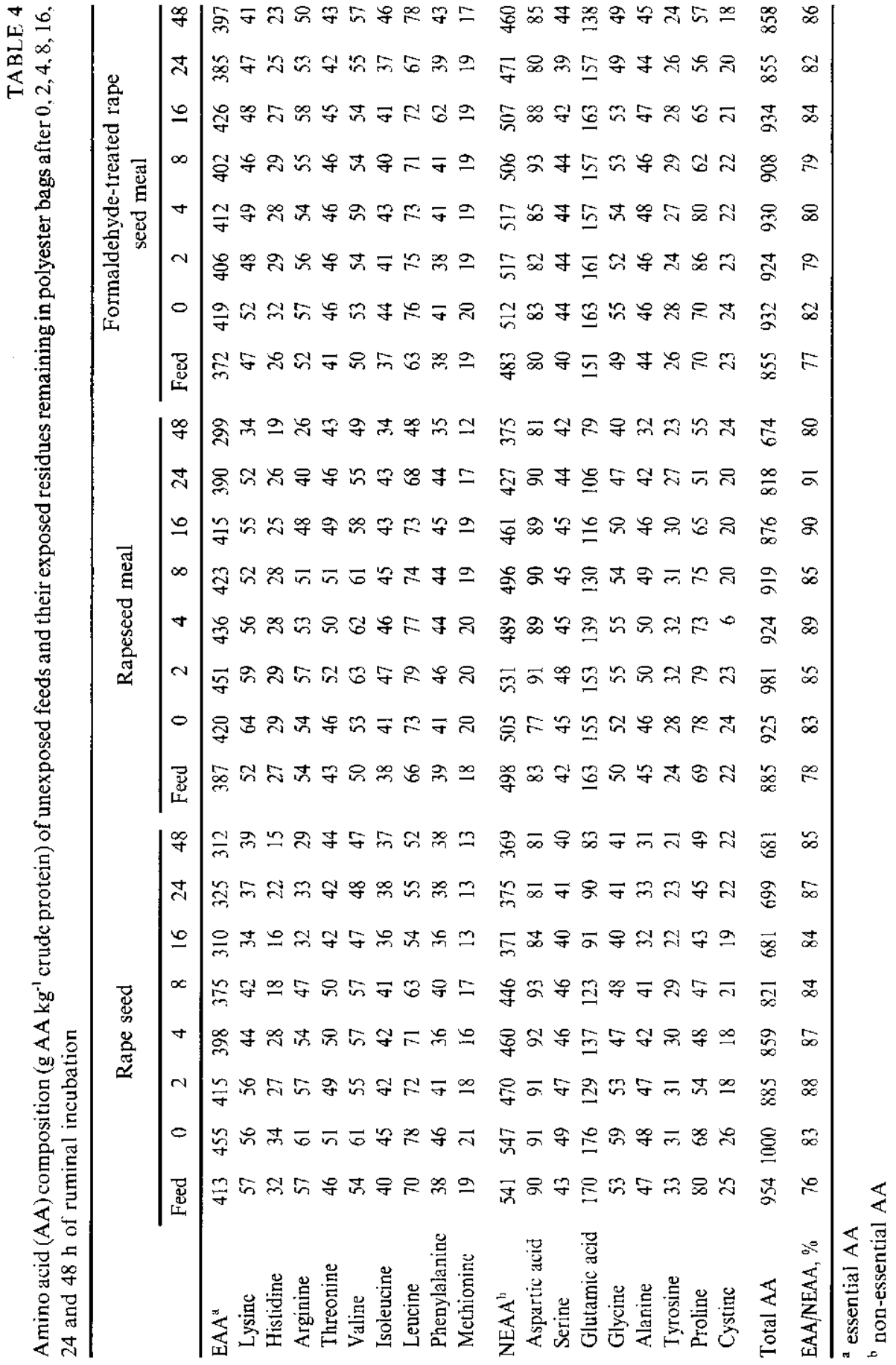



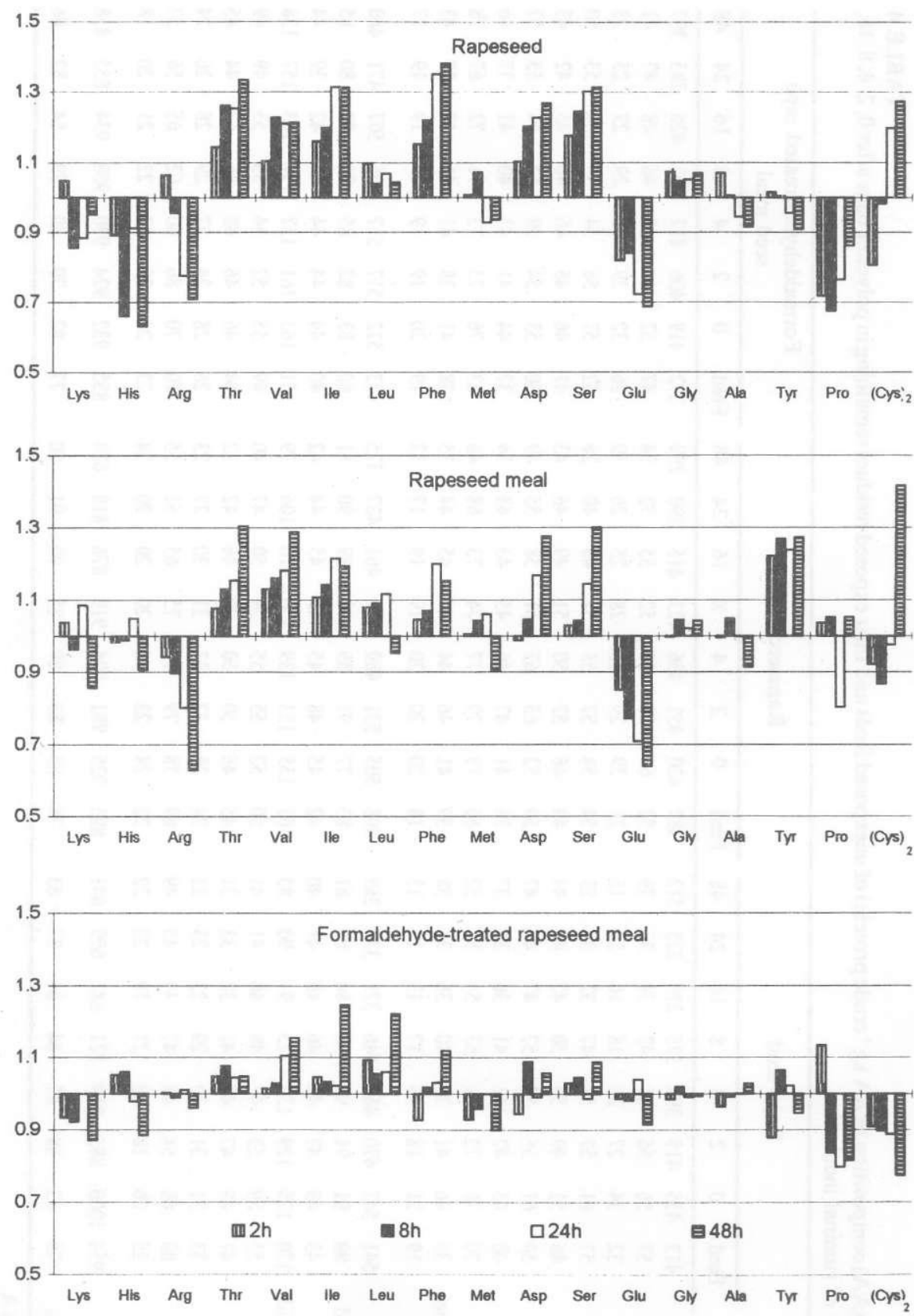

Figure 1. Comparison of the amino acids (AA), calculated as $\mathrm{gAA} / \mathrm{g}$ of total $\mathrm{AA}$, of the original and undegraded protein of polyester bag residues exposed to the rumen for 2, 8, 24 and $48 \mathrm{~h}$ in the three rape seed commodities (exposed feed/unexposed feed) 
点

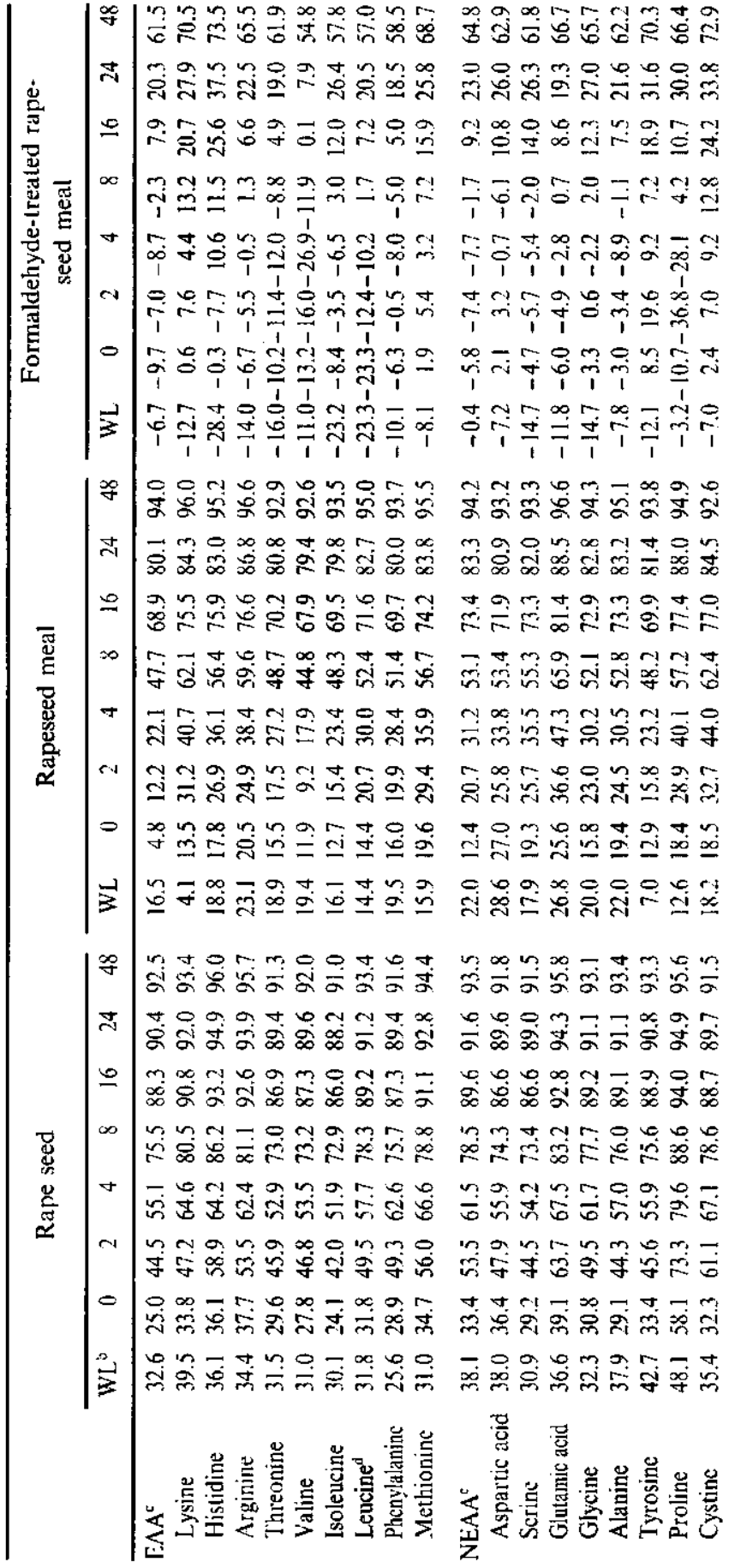

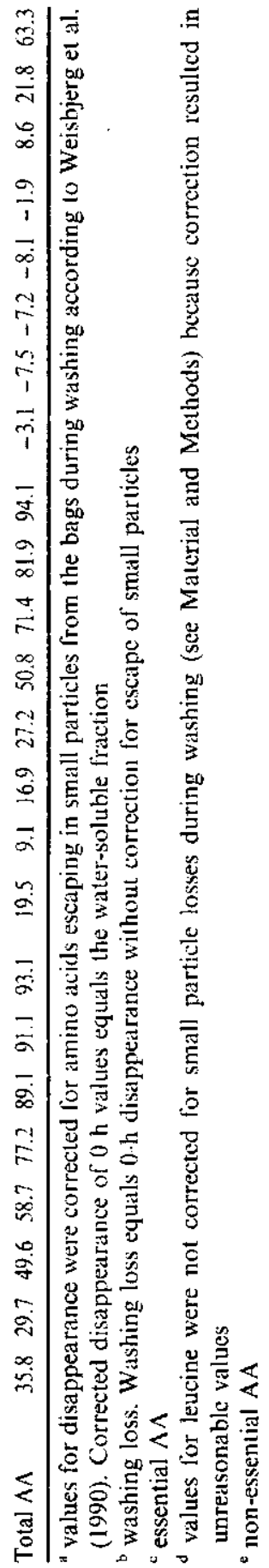




\section{DISCUSSION}

The glucosinolate contents of the three rape seed commodities were similar to the lower range values reported for double-improved rape seed harvested at 61 and 52 locations throughout Germany in the years 1991 and 1992, respectively (Sauermann, 1995). Matyka et al. (1992) reported that 11 samples of Polish rape seed contained less than $25 \mu \mathrm{mol}$ glucosinolates per gram of defatted matter. Ochodzki et al. (1995) found that glucosinolate contents for 38 dark-seeded double-improved Polish rape seed samples were in the range of 8 to $20 \mu \mathrm{mol} / \mathrm{g}$ seed. Based on the observation that glucosinolates had completely disappeared from the rape seed commodities after only $4 \mathrm{~h}$ of ruminal exposure, it would be important to know whether the glucosinolates had only been released from the feeds or broken down to toxic moieties, which could affect ruminal microorganisms or, after absorption, the ruminant animal. Subuh et al. (1995) investigated the occurrence of four toxic moieties that are released when glucosinolates are hydrolyzed enzymatically, in the rumen contents of heifers. The animals received $4 \mathrm{~kg}$ daily of concentrates containing $300 \mathrm{~g} / \mathrm{kg}$ of either low glucosinolate or high glucosinolate RSM in untreated, heat-treated or formaldehyde-treated form. Thiocyanates were detected, though in small quantities, as early as 15 min after feeding the RSM containing diets. Other toxic moieties could not be detected in ruminal digesta. Moreover, there were no effects of glucosinolate contents or treatment on the level of thiocyanates in ruminal digesta (Subuh et al., 1995). Irrespective of glucosinolate level of RSM and treatment imposed upon RSM, the authors indicated that mild hepatic damage had occurred in the heifers. The total glucosinolate concentration of their low glucosinolate RSM, however, was 28 to $30.3 \mu \mathrm{mol} / \mathrm{g}$ feed, which is much higher than the values determined in the rape seed commodities of the present study.

Although numerous in situ studies have been conducted on ruminal degradation of DM and CP of rape seed and RSM meal, either untreated or treated with a variety of chemicals, a direct comparison of data should be undertaken with caution for two reasons. Most of the European studies have used Brassica varieties of medium to high glucosinolate contents, which may differ from low glucosinolate varieties in their DM and CP degradation characteristics (Subuh et al., 1994). The majority of North-American studies were based on double-low (low erucic acid, low glucosinolates) seeds and meals but several authors used spring sown B. campestris varieties with yellow hulls, which may differ from dark-seeded varieties with respect to nutritive value due to differences in seed coat morphology (Bell and Shires, 1982). In our study, data for disappearance of DM and CP from the polyester bags were corrected by subtraction for the proportion of small particles that theoretically would still be in the bag at a specific incubation time (Weisbjerg et al., 1990). Because this correction affects 
the nonlinear parameter estimates and the effective degradabilities derived from those estimates, values for DM and CP degradability from our study appear to be generally lower than those of earlier studies, where corrections for small particles losses have not been included in the estimates. This difference in modelling the degradation kinetics, however, should not influence the comparison among the three commodities rape seed, RSM and FRSM.

The three rape seed commodities differed in characteristics of ruminal degradation. Effective ruminal degradabilities of CP in RSM at assumed ruminal passage rates of 2 and $5 \% / \mathrm{h}$ were within the range (59 to $77 \%$ ) summarized by Hill (1991) and recently confirmed by Krastanova et al. (1994) for untreated RSM. The effective degradability at a ruminal passage rate of $8 \% / \mathrm{h}$, however, was considerably lower $(50.8 \%)$. Effective CP degradability values for RSM $\geqslant 80 \%$ have recently been observed by Daccord (1993), Moss and Givens (1994) and Subuh et al. (1994). Available information on CP degradability thus only allows untreated RSM to be categorized as a feed of medium to high CP degradability or, vice versa, a medium to poor source of rumen undegradable CP. The variation in CP degradability values of RSM could partly be attributed to rape seed varieties and to soil conditions, climate and geographic location where the rape seed was grown (Hill, 1991). Other factors contributing to variation in rumen degradabilities are variation in the temperatures during the toasting phase of processing the RSM (Lardy et al., 1993) and different protocols for the in situ procedure and the mathematical treatment of the data derived from ruminal incubations.

The DM and CP of the rape seed were more effectively degraded in the rumen than that of RSM, which is in accordance with the findings of Deacon et al. (1988). However, Mir et al. (1984) reported that RSM (canola) had slightly higher CP degradabilities than rape seed. Although rape seed had a higher ruminal DM degradability than RSM, the amount of DM per $\mathrm{kg}$ feed that can be fermented ruminally will be greater for RSM due to the fact that a significant proportion of ruminally degraded DM in rape seed is fat. This is released from the seed and disappears through the bag pores during ruminal incubation but only the glycerol portion of fat is readily fermented (Hvelplund and Madsen, 1985). Fatty acids are not available as a source of energy to ruminal microorganisms because organisms degrading fatty acids grow too slowly to exist in the rumen (Nocek and Russell, 1988).

Treatment of RSM with formaldehyde was very effective in reducing rate and extent of $\mathrm{CP}$ degradation and thus increasing the proportion of rumen undegradable $\mathrm{CP}$, which is consistent with findings of several other researchers (Ha and Kennelly, 1984; Mir et al, 1984; Setälä and Syrjälä-Qvist, 1984; Deacon et al., 1988; Krastanova et al., 1994; Subuh et al., 1994). Extent of reduction in ruminal degradability and degradation rate of $\mathrm{CP}$ depends on the level and 
method of treatment with formaldehyde (Setälä and Syrjälä-Qvist, 1984). Antoniewicz et al. (1992b) demonstrated that RSM was more susceptible than other feeds (lupins, peas, field beans) to reduced intestinal CP digestibility caused by irreversible protection of $\mathrm{CP}$ through treatment with formaldehyde. In the present study, the low level of formaldehyde $(1.1 \mathrm{~g} / \mathrm{kg} \mathrm{DM}$, which is equivalent to $3.1 \mathrm{~g} / \mathrm{kg} \mathrm{CP}$ ), applied in gaseous form under pressure, dramatically reduced effective degradability of CP and, to a lesser extent, DM. This level was far below the range of 10 to $20 \mathrm{~g}$ liquid formaldehyde per $\mathrm{kg} \mathrm{CP}$, which has been reported to be critical for $\mathrm{CP}$ digestion in, and $\mathrm{AA}$ absorption from the small intestine (Ashes et al., 1984). When RSM was treated with formaldehyde in liquid form, $8 \mathrm{~g}$ of formaldehyde per $\mathrm{kg}$ CP were necessary to reduce ruminal $\mathrm{CP}$ degradation by $50 \%$ without negatively affecting digestibility of $\mathrm{CP}$ in the lower tract (Krawielitzki et al., 1982). A lower optimum level $(5 \mathrm{~g} / \mathrm{kg} \mathrm{CP})$ for protecting soyabean meal CP from ruminal degradation without hindering post-ruminal digestion has been reported by Voigt et al. (1985), who applied formaldehyde in gaseous form at atmospheric pressure and room temperature.

The observed increase in the AA content of the CP of all three feeds after washing indicated that primarily non-protein, non-AA nitrogen was washed out of the bags. The increase in the ratio of EAA to NEAA further suggests that the AA fraction, which could be washed out without ruminal incubation, contained relatively more NEAA than EAA. Information on the degree of conformity in the AA protile of feed $\mathrm{CP}$ versus rumen undegraded $\mathrm{CP}$ is of key importance, when in situ $\mathrm{CP}$ degradabilities and AA profiles of the undegraded feeds are combined to predict the AA profile of the $\mathrm{CP}$ reaching the small intestine (Tagari et al., 1995). As a result of ruminal incubation, the AA profile of the rape seed commodities varied among feeds and AA. Within-feed variation was notable for rape seed and RSM and increased with longer ruminal cxposure. Varvikko et al. (1983) and Setälä and Syrjälä-Qvist (1984) noted that rumen fermentation generally had a small effect on the AA compositon of RSM. This effect was even smaller with longer ruminal residence time (Setälä and Syrjälä-Qvist, 1984). In the work conducted by Varvikko et al. (1983), however, methionine and glutamic acid were degraded to a greater extent than the other $A A$. $\Lambda$ rapid degradation in the rumen of glutamic acid, but not of methionine, was also reported for rape seed by Varvikko (1986) and confirmed in this study. The branched-chain AA of rape seed have been reported to be more resistant to ruminal degradation than other AA by Varvikko (1986) and Antoniewicz et al. (1992a). Kendall et al. (1991) reported that the in situ disappcarance of histidine, methionine and cystine differed from those of other AA up to $16 \mathrm{~h}$ of ruminal incubation. Compared with the average AA disappearance, the values were lower for methionine and higher for histidine. In our study, treatment with formaldehyde not only reduced AA disappearance but also resulted in a more uniform pattern of ruminal 
disappearance of AA compared with rape seed and RSM. Thus, for FRSM, it should be possible to calculate the post-ruminal supply of rumen undegraded AA from the effective degradability value of CP and the AA composition of the feed CP as suggested by Tagari et al. (1995), without necessitating time- and labourconsuming AA analyses of the undegraded feed residues. According to our findings, the respective values for rape seed and RSM, however, can not be derived in this simple way but must additionally include estimates of the $\mathrm{A} \Lambda$ compostion of the undegraded CP. Similarly, Cozzi et al. (1995) concluded from their study on ruminal AA disappearance of four different meals (soyabean, maize gluten, herring and meat) that ,use of the original AA profile of the feed protein to predict essential AA available for absorption is not accurate because accuracy differs with sources".

\section{CONCLUSIONS}

Our data support earlier observations that within and between feed variation in ruminal degradation characteristics of $\mathrm{DM}, \mathrm{CP}$ and $\mathrm{AA}$ are large for rape seed and untreated RSM. Between feed variation should be accounted for when these feeds are included in ruminant diets. The treatment of FRSM with gaseous formaldehyde was very effective in reducing the extent and rate of ruminal $\mathrm{CP}$ degradation and in preserving the $\Lambda \mathrm{A}$ profile of the original feed during ruminal incubation in situ, which would allow calculating the post-ruminal supply of rumen undegraded $\mathrm{AA}$ in $\mathrm{FRSM}$ from the effective degradability value of $\mathrm{CP}$ and the AA composition of CP of the feed.

\section{ACKNOWLEDGMENTS}

This study was supported by a grant (No. 524/932) from the Union zur Förderung von Oel- und Proteinpflanzen (UFOP e. V., Bonn, Germany). The three rape seed commodities were kindly donated by A. Helmedach. We thank Mr. C. Lewin for care of the steers and Mrs. S. Bremer and Prof. M. Gabel, University of Rostock, Germany, for amino acid analyses. 


\section{REFERENCES}

Agricultural Research Council, 1984. The Nutrient Requirements of Ruminant Livestock, Suppl. No. 1. Commonwealth Agric. Bureaux, Farnham Royal

Anonymous, 1990. Verordnung (EWG) Nr. 1864/90. Anhang VIIl. Bestimmung des Ölsaaten Glucosinolatgehaltes durch HPLC. Amtsblatt der Europäischen Gemeinschaften No. L 170, 28-34

Antoniewicz A., Pisulewski P., Szymczyk B., 1992a. Enzymatic solubility and amino acid composition of rumen undegraded protein of natural and formaldehyde-treated full-fat rape seeds (in Polish). Rocz. Nauk. Zoot. 19, 101-111

Antoniewicz A.M., van Vuuren A.M., van der Koelen C.J., Kosmala I., 1992b. Intestinal digestibility of rumen undegraded protein of formaldehyde-treated feedstuffs measured by mobile bag and in vitro technique. Anim. Feed Sci. Technol. 39, 111-124

Ashes J.R., Mangan J.L., Sidhu G.S., 1984. Nutritional availability of amino acids from protein cross-linked to protect against degradation in the rumen. Brit. J. Nutr. 52, 239-247

Bailey C.B., Hironaka R., 1984. Estimation of the rumen degradability of nitrogen and of nonprotein organic matter in formaldehyde-treated and untreated canola meal. Can. J. Anim. Sci. 64, 183-185

Bassler R. (Editor), 1976. Die chemische Untersuchung von Futtermitteln. Methodenbuch, Vol. 3 mit Ergänzungslieferungen 1983, 1988, 1993. VDLUFA-Verlag, Darmstadt

Bell J.M., 1993. Factors affecting the nutritional value of canola meal: A review. Can. J. Anim. Sci. $73,679-697$

Bell J.M., Shires A., 1982. Composition and digestibility by pigs of hull fractions from rape seed cultivars with yellow and brown seed coats. Can. J. Anim. Sci. 62, 557-565

Cozzi G., Andrighetto I., Berzaghi P., Polan C.E., 1995. In situ ruminal disappearance of essential amino acids in protein feedstuffs. J. Dairy Sci. $78,161-171$

Daccord R., 1993. Protein value of rapeseed oil meal for ruminants. GCIRC Bull. 9, 119-120

Deacon M.A., De Boer G., Kennelly J.J., 1988. Influence of Jet-Sploding ${ }^{\mathbb{B}}$ and extrusion on ruminal and intestinal disappearance of canola and soybeans. J. Dairy Sci. 71, 745-753

Ha J.K., Kennelly J.J., 1984. In situ dry matter and protein degradation of various protein sources in dairy cattle. Can. J. Anim. Sci. 64, 443-452

Hill R., 1991. Rape seed meal in the diets of ruminants. Nutr. Abstr. Rev., Ser. B 61, 139-155

Hvelplund T., Madsen J., 1985. Amino acid passage to the small intestine in dairy cows compared with the estimates of microbial protein and undegraded dietary protein from analysis of the feed. Acta Agric. Scand., Suppl. 25, 21-36

Kendall E.M., Ingalls J.R., Boila R.J., 1991. Variability in the rumen degradability and postruminal digestion of dry matter, nitrogen and amino acids of canola mcal. Can. J. Anim. Sci. 71, 739-754

Krastanova M., Lebzien P., Rohr K., 1994. Verglcich von in vivo und in situ ermittelten Werten für den Futterproteinabbau im Pansen und das Aminosäurenmuster des unabgebauten Futterproteins. J. Anim. Physiol. Anim. Nutr. 72, 92-100

Krawielitzki R., Piatkowski B., Voigt J., 1982. Untersuchungen zur Behandlung von Rapsextraktionsschrot und Leinsamenextraktionsschrot mit Formaldehyd. Arch. Ticrernähr. 32, 763-777

Lardy G.P., Catlett G.E., Kerley M.S., Paterson, J.A., 1993. Determination of the ruminal escape value and duodenal amino acid tlow of rapeseed meal. J. Anim. Sci. 7l, 3096-3104

Matyka S., Jaśkiewicz T., Bogusz G., Korol W., 1992. A note on the chemical composition of low glucosinolate rape seed produced in North-Eastern Poland. J. Anim. Feed Sci. I, 177-182

McDonald I.M., 1981. A revised model for the estimation of protein degradability in the rumen. $J$. Agric. Sci., Camb. 92, 251-252 
Mir Z., MacLeod G.K., Buchanan-Smith J.G., Grieve D.G., Grovum W.L., 1984. Methods for protecting soybean and canola proteins from degradation in the rumen. Can. J. Anim. Sci. 64, 853-865

Moss A.R., Givens D.I., 1994. The chemical composition, digestibility, metabolisable energy content and nitrogen degradability of some protein concentrates. Anim. Feed Sci. Technol. 47, 335-351

Nocek J.E., Russell J.B., 1988. Protein and energy as an integrated system. Relationship of ruminal protein and carbohydrate availability to microbial protein synthesis and milk production. $\mathbf{J}$. Dairy Sci. 71, 2070-2107

Ochodzki P., Rakowska M., Bjergegaard C., Sørensen H., 1995. Studies on enzymatic fractionation, chemical composition and biological effects of dietary fibre in rape seed (Brassica napus L.). 1. Chemical composition of secds and charactcristics of soluble and insoluble dietary fibre of spring and winter type varieties of double improved oilseed rape. J. Anim. Feed Sci. 4, 127-138

Rooke J.A., Brookes I.M., Armstrong D.G., 1983. The digestion of untreated and formaldehyde-treated soyabean and rapeseed meals by cattle fed a basal silage diet. J. Agric. Sci., Camb. 100, 329-342

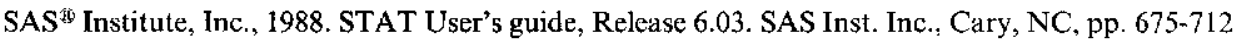

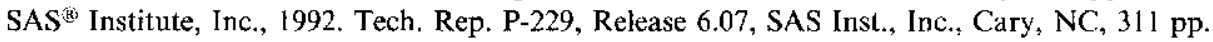

Sauermann W., 1995. Der Glucosinolatgehalt von Winterraps in Abhängigkeit von Standort und Sorte. In: Erfassung und Bcwertung von fruchtartenspezifischen Eigenschaften bei Raps und Sonnenblumen. UFOP-Schriften 1, 21-36

Setälä J., Syrjälä-Qvist L., 1984. Degradation of crude protein and quality of undegradable protein in untreated or formaldehyde-treated rapeseed meal. Anim. Feed Sci. Technol. 12, 19-27

Subuh A.M.H., Rowan T.G., Lawrence T.L.J., 1994. Effect of heat or formaldehyde treatment and differences in basal diet on the rumen degradability of protcin in soyabean meal and in rapeseed meals of different glucosinolate content. Anim. Fced Sci. Technol. 49, 297-310

Subuh A.M.H., Rowan T.G., Lawrence T.L.J., 1995. Toxic moities in ruminal and duodenal digesta and in milk, and hepatic integrity in cattle given diets based on rapeseed meals of different glucosinolate contents either untreated or treated with heat or formaldehyde. Anim. Feed Sci. Technol. 52, 51-61

Tagari H., Arieli A., Mabjeesh S., Bruckental I., Zamwell S., Aharoni Y., 1995. Assessment of duodenal amino acid profile in dairy cows by the in situ method. Livest. Prod. Sci. 42, 13-22

Varvikko T., 1986. Microbially corrected amino acid composition of rumen-undegraded feed protein and amino acid degradability in the rumen of feeds enclosed in nylon bags. Brit. J. Nutr. 56, $131-140$

Varvikko T., Lindberg J.E., 1985. Estimation of microbial nitrogen in nylon-bag residues by feed ${ }^{15} \mathrm{~N}$ dilution. Brit. J. Nutr. \$4, 473-481

Varvikko T., Lindberg J.E., Setälä J., Syrjälä-Qvist L., 1983. The effect of formaldehyde treatment of soya-bean meal and rapeseed meal on the amino acid profiles and acid-pepsin solubility of rumen undegraded protein. J. Agric. Sci., Camb. 101, 603-612

Voigt J., Chrastinová L., Piatkowski B., Schönhusen U., Krawielitzki R., 1985. Untersuchungen zur Optimierung der Formaldehyddosis bei der Behandlung von Sojaextraktionsschrot. Arch. Tierernähr. 35, 321-330

Wcisbjerg M.R., Bhargava P.K., Hvelplund T., Madsen J., 1990. Anvendelse af nedbrydningsprofiler i fodermiddelvurderingen. Beretning fra Statens Husdyrbrugsforsøg No. 679. Tjele, 33 pp. 


\section{STRESZCZENIE}

Ocena wartości rodzajów pasz rzepakowych w żwaczu buhajków. 1. Trawienie suchej masy i bialka ogólnego oraz ubytek aminokwasów

Szybkość i rozmiar trawienia suchej masy, białka ogólnego oraz ubytku aminokwasów z nasion rzepaku, poekstrakcyjnej śruty rzepakowej zwykłej lub traktowanej formaldehydem. zawierającej w 1 g suchej masy mniej niż $8 \mu \mathrm{m}$ glukozynolanów, oznaczano, inkubując te pasze w woreczkach z tkaniny policstrowcj umicszczonych w żwaczu 3 buhajków przez $0,2,4,8,12,24, i 48$ godzin. Białko ogólne było łalwiej trawione niż sucha masa nasion rzepaku i poekstrakcyjnej śruty zwyklej niż. traktowanej formaldehydem. Wartość efektywnego rozkładu suchej masy i białka ogólnego nasion rzepaku byla największa, pośrednia dla poekstrakcyjnej śruty rzepakowej zwykłej, a najniższa dla śruty formaldehydowanej. Efekıywny rozkład białka ogólncgo, przy założeniu tempa wypływu treści ze żwacza 2,5 i $8 \%$ /godz, osiągnął wartości od 77 do $62 \%$ w przypadku nasion rzepaku, 76 do $51 \%$ poekstrakcyjnej śruty zwykłej i 39 do $16 \%$ śruty formaldehydowanej. Profil aminokwasowy białka śrul nie poddanych działaniu formaldehydu, pozostalego po inkubacji, zmieniał się w miarę upływu czasu ich inkubacji w żwaczu, w wyniku czego wystąpiły duże różnice w ilości ubytku poszczególnych aminokwasów z tych pasz. Sklad poekstrakcyjnej śruty formaldehydowanej byl podobny przed i po inkubacji w źwaczu. 